\title{
NOTES/NOSE/NOSCAR/LATAS: What does it all mean?
}

\author{
S.D. Wexner • Y. Edden
}

Published online: 14 March 2009

(C) Springer-Verlag 2009

For 15 years colorectal surgeons seemed immune to the contagious excitement which surrounded the development of laparoscopic surgery in the late 1980s and early 1990s. The unique patient benefits were ignored and even refuted as some general surgeons referred to laparoscopy as a "virus" [1]. This "virus" was proven to actually be the most important advance in surgery since Ravitch and Steichen popularized surgical stapling [2-5]. As the enthusiasm transcended platforms from cholecystectomy to hernia and appendectomy and from gastroesophageal reflux treatment to solid organ surgery, entire surgical specialties were born and reborn. As an example, morbid obesity surgery was suddenly transformed into a very popular field which has recently morphed into metabolic surgery. However, colorectal surgery lagged behind [6].

The unique challenges of working in multiple quadrants with the need for extensive vascular control within an often thick friable mesentery, the requirement for anastomosis, and the surgical indications such as inflammatory bowel disease and neoplasia, dampened enthusiasm [7, 8]. Reports of port site metastases further decelerated the adoption of the techniques and the penetration of the procedures $[9,10]$. Finally after the COST trial was present-

S.D. Wexner $(\bowtie) \cdot$ Y. Edden

Department of Colorectal Surgery

Cleveland Clinic Florida

2950 Cleveland Clinic Blvd.

Weston, Florida 33331, USA

Tel.: +1-954-6595133

Fax: +1-954-6595184

E-mail: deanh@ccf.org ed at the May 2004 meeting of the American Society of Colon and Rectal Surgeons (ASCRS) and simultaneously published in the New England Journal of Medicine [11] acceptance accelerated. Patients, surgeons, and our partners in industry began the quest for the next paradigm shift. Several contenders have emerged including robotic surgery [12], single port access or single incision access surgery $[13,14]$, and natural orifice transluminal endoscopic surgery (NOTES) [15].

This latter group of techniques was best evaluated under the direction of the Society of American Gastrointestinal and Endoscopic Surgeons (SAGES) and the American Society of Gastrointestinal Endoscopic Surgeons (ASGE) through the joint Natural Orifice Surgery Consortium for Advancement and Research (NOSCAR) [16]. Interestingly, NOTES was already familiar to all colorectal surgeons thanks to the indefatigable efforts of Professor Gerhard Buess from Tübingen, Germany, who pioneered and disseminated to the world transanal endoscopic microsurgery (TEM) [17]. TEM was clearly a direct ancestor in the lineage to NOTES; in recent years the synergy from minimally invasive surgery has given TEM a huge boost.

Many more centres now have TEM surgery available and the results of Buess have been reproduced throughout the world [18-20]. Colorectal surgeons should have a second natural advantage relative to NOTES - since NOTES demands flexible endoscopic skills, and colorectal surgeons have always included therapeutic colonoscopy as a core competency, the requisite technical abilities should already have been acquired. Recognizing the need for these skills, the American Board of Surgery recently adopted a required minimum number of flexible endoscopic procedures for all general surgery residents [21, 22]. 
The outcome of the convergence of slow adoption of laparoscopy with excellent flexible endoscopic skills and familiarity with TEM has led to an interesting development - transanal specimen extraction and anastomosis. Numerous surgeons have described and demonstrated both the technical aspects and the results [23-25]. As early as the early 1990s Morris Franklin from San Antonio, Texas awed us with magnificent videos of transanal specimen removal. There certainly remain many questions - what is the effect, if any, on faecal continence and on oncological outcomes? Moreover the technique is very demanding. Despite these potential obstacles and unanswered questions the technique has been described in many ways. In 2005 we presented at SAGES our method of totally laparoscopic low anterior resection with a transperineal hand-sewn colonic $\mathrm{J}$ pouch anal anastomosis for low rectal cancer. The technique was subsequently published in Surgical Endoscopy [26] and released in video form online [27]. John Marks from Lankenau Hospital in Pennsylvania has adopted the transabdominal transanal (TATA) techniques of his father, Gerald Marks, into the realm of laparoscopy [28, 29] and others have shown similar enthusiasm [30].

This issue of Techniques in Coloproctology contains two more variations on the theme [31, 32]. The common thread is that many of us are striving for a way to minimize or avoid incisions and to optimize outcomes. However, not everyone has either the time or interest to conquer the challenges. While Leroy and Marescaux in Strasbourg, France, and Swanstrom and Whiteford in Portland, Oregon, have routinely pushed the NOTES applications in colorectal surgery [15,33], the rest of the world has largely watched with mixed emotion. Both of the currently published articles are indicative of the desire to advance the borders of NOTES within colorectal surgery; they also show that many different methods may be applied towards the same end. We congratulate both sets of authors for trying to give patients the best possible outcome with the least possible coetaneous trauma. We also encourage other surgeons who feel capable of handling the challenges to try to employ these techniques in a monitored setting. However, realistically we do not imagine that we will have a large database or the answers to the many outstanding uncertainties in the near future.

\section{References}

1. Keith RG (1990) Laparoscopic cholecystectomy: let us control the virus. Can J Surg 33:435-436

2. Ravitch MM, Steichen FM, Fishbein RH et al (1964) Clinical experiences with the Soviet mechanical bronchus stapler (UKB25). J Thorac Cardiovasc Surg 47:446-454
3. Ravitch MM, Steichen FM (1972) Technics of staple suturing in the gastrointestinal tract. Ann Surg 175:815-837

4. Steichen FM, Ravitch MM (1973) Mechanical sutures in surgery. Br J Surg 60:191-197

5. Ravitch MM, Steichen FM (1984) Staples and staplers. Adv Surg 17:241-279

6. Jacobs M, Verdeja JC, Goldstein HS (1991) Minimally invasive colon resection (laparoscopic colectomy). Surg Laparosc Endosc $1: 144-150$

7. Wexner S, Johansen OB (1992) Laparoscopic bowel resection: advantages and limitations. Ann Med 24:105-110

8. Reissman P, Salky BA, Pfeifer J et al (1996) Laparoscopic surgery in the management of inflammatory bowel disease. Am J Surg 171:47-50

9. Jorgensen JO, McCall JL, Morris DL (1995) Port site seeding after laparoscopic ultrasonographic staging of pancreatic carcinoma. Surgery 117:118-119

10. Wexner SD, Cohen SM (1995) Port site metastases after laparoscopic colorectal surgery for cure of malignancy. Br J Surg 82:295-298

11. Clinical Outcomes of Surgical Therapy Study Group (2004) A comparison of laparoscopically assisted and open colectomy for colon cancer. N Engl J Med 350:2050-2059

12. Anvari M, Birch DW, Bamehriz F et al (2004) Robotic-assisted laparoscopic colorectal surgery. Surg Laparosc Endosc Percutan Tech 14:311-315

13. Leroy J, Cahill RA, Peretta S et al (2008) Single port sigmoidectomy in an experimental model with survival. Surg Innov 15:260-265

14. Tacchino R, Greco F, Matera D (2008) Single-incision laparoscopic cholecystectomy: surgery without a visible scar. Surg Endosc DOI: $10.1007 / \mathrm{s} 00464-008-0318-\mathrm{x}$

15. Whiteford MH, Denk PM, Swanström LL (2007) Feasibility of radical sigmoid colectomy performed as natural orifice translumenal endoscopic surgery (NOTES) using transanal endoscopic microsurgery. Surg Endosc 21:1870-1874

16. Al-Akash M, Boyle E, Tanner WA (2008) NOTES: The progression of a novel and emerging technique. Surg Oncol. DOI: 10.1016/j.suronc.2008.11.003

17. Buess G (1991) Transanal microsurgery. Langenbecks Arch Chir Suppl Kongressbd 441-447

18. Lirici MM, Chiavellati L, Lezoche E et al (1994) Transanal endoscopic microsurgery in Italy. Endosc Surg Allied Technol 2:255-258

19. Yamashita Y, Sakai T, Maekawa T et al (1998) Clinical use of a front lifting hood rectoscope tube for transanal endoscopic microsurgery. Surg Endosc 12:151-153

20. Kanehira E, Yamashita Y, Omura K et al (2002) Early clinical results of endorectal surgery using a newly designed rectal tube with a side window. Surg Endosc 16:14-17

21. Kann BR, Margolin DA, Brill SA et al (2006) The importance of colonoscopy in colorectal surgeons' practices: results of a survey. Dis Colon Rectum 49:1763-1767

22. Accreditation Council for Graduate Medical Education (2009) General surgery defined category mappings. www.acgme.org/acWebsite/downloads/oplog/440CatMin.pdf. Accessed 8 Feb 2009

23. Sylla P, Willingham FF, Sohn DK et al (2008) NOTES rectosigmoid resection using transanal endoscopic microsurgery (TEM) with transgastric endoscopic assistance: a pilot study in swine. J Gastrointest Surg 12:1717-1723

24. Zoller S, Joos A, Dinter D et al (2007) Retrorectal tumors: excision by transanal endoscopic microsurgery. Rev Esp Enferm Dig 99:547-550

25. Darwood RJ, Wheeler JM, Borley NR (2008) Transanal endoscopic microsurgery is a safe and reliable technique even for complex rectal lesions. Br J Surg 95:915-918 
26. Person B, Vivas DA, Wexner SD (2006) Totally laparoscopic low anterior resection with transperineal handsewn colonic Jpouch anal anastomosis for low rectal cancer. Surg Endosc 20:700-727

27. Wexner SD (2009) SAGES educational video library. Laparoscopic low anterior resection and transanal mucosectomy, with transperineal construction of colonic j-pouch and handsewn coloanal anastomosis for low rectal cancer. http://cinemed.net/sages/?association=SAGES\&CatalogNumber=MS1237. Accessed 8 Feb 2009

28. Bannon JP, Marks GJ, Mohiuddin M et al (1995) Radical and local excisional methods of sphincter-sparing surgery after highdose radiation for cancer of the distal $3 \mathrm{~cm}$ of the rectum. Ann Surg Oncol 2:221-227

29. Marks GJ, Bannon JP, Marks JH (1997) Transanal-abdominalradical proctosigmoidectomy with coloanal anastomosis for dis- tal rectal cancer. In: Nyhus L, Baker R, Fischer J (eds) Mastery of surgery, vol. II, 3rd edn. Little, Brown and Company, Boston, MA

30. Zhou JN, Wang DZ, Huang XE et al (2006) Transabdominal transanal resection of distal rectal cancer after high dose preoperative radiotherapy: a Chinese experience in preserving sphincter function. Isr Med Assoc J 8:675-678

31. Knol J, D'Hondt M, Dozois EJ et al (2009) Laparoscopic assisted transanal sigmoidectomy with Transanal Specimen Extraction: a bridge to NOTES? Tech Coloproctol 13:65-68

32. Ooi BS, Quah HM, Fu CWP, Eu KW (2009) Laparoscopic high anterior resection with natural orifice specimen extraction (NOSE) for early rectal cancer. Tech Coloproctol 13:61-64

33. Leroy J, Cahill RA, Perretta S et al (2009) Natural orifice translumenal endoscopic surgery (NOTES) applied totally to sigmoidectomy: an original technique with survival in a porcine model. Surg Endosc 23:24-30 